\title{
The Crisis of Meaning as a Turning Point in Human Life
}

\section{Криза сенсу як переломний момент \\ життя людини}

\author{
Halyna Chuiko \\ Галина Чуйко \\ Ph.D. in Philology, \\ Assistant Professor
кандидат філологічних наук, доцент \\ E-mail: halynka2244@ukr.net \\ orcid.org/0000-0002-3424-3348 \\ Researcher ID: D-9477-2D16 \\ Yuriy Fedkovych Chernivtsi \\ National University, \\ Chernivtsi, Ukraine \\ 2, Kotsiubynskoho street, \\ Chernivtsi, Chernivetskyi \\ region, 58012 \\ Чернівецький національний \\ університет імені \\ Юрія Федьковича, \\ м. Чернівиі, Украӥна \\ вул. Коцюбинського, 2 , \\ м. Чернівці, Україна, 58012 \\ Original manuscript received April 24, 2019 \\ Revised manuscript accepted May 05, 2019
}

\section{ABSTRACT}

The article is devoted to the theoretical analysis of the phenomenon of crisis of the meaning of life, its peculiarities, manifestations and consequences for life of the personality, as well as hardiness as a possible barrier to the acute and prolonged human experience of the crisis of the meaning of life (similarly to coping the stress and transforming it into the possibility of learning lessons from its passing and personal growth).

It is noted that the crisis of the meaning of life is the most important event on the life path of the personality, it is experienced particularly acute, because of the power of influence on a person, his / her further life and the 
possible catastrophic consequences, although it occurs less often than other personal crises.

The views on the crisis of the meaning of life and its specifics of famous foreign psychologists (F. Ye. Vasiliuk, K. V. Karpinskyi, S. Maddi, V. Frankl, V. E. Chudnovsky, I. Yalom etc.) were considered. It is noted that what V. Frankl called the experience of an existential vacuum with its corresponding consequences, I. Yalom - a crisis of meaning or a crisis of senselessness, and S. Mad$d y-a$ "small death" or existential neurosis, K.V. Karpinskyi uses the name of the crisis of the meaning of life, which is understood as a semantic crisis in the development of personality, which blocks primarily the semantic regulation and processes of creation of sense of the individual life path and defines its main manifestations, the reason for which are the problems of searching or realizing of the meaning of life of personality.

It is revealed that the crisis of the meaning of life is experienced by a human as a long and / or sharp internal conflict between the desirable (vitally necessary, super important for him) and objectively possible event. At this time, the man, even imagining the way to achieve the desire, can't always use it, this makes him/her accept everything as it is, and try to cope with the situation. It is impossible to separate internal and external causes, in the experiencing the crisis of the meaning of life, since it is always experienced at the subjective level.

It is concluded that hardiness can be used to overcome the crisis of the meaning of life of the personality, minimizing its negative consequences and transforming it into the possibility of personality's development through learning of life lessons and finding a new personal sense of life.

Key words: crisis of the meaning of life, hardiness, meaning of life, commitment, existential neurosis, crisis of senselessness.

\section{Вступ}

Відмітною рисою сучасної людини є втрата відчуття безпеки у світі, де людське життя позбавлене своєї самоцінності. Зовнішні об'єктивно існуючі й ті, що лише представляються людині такими, загрози на суб'єктивному, внутрішньому рівні провокують тривогу, переживаються нею як стресові чи кризові ситуації, посилюючись за рахунок внутрішньої нестабільності існування людини через їі невпевненість у завтрашньому дні й очікуванні прогнозованого гіршого. На цьому тлі особливо гостро пережива- 
ються життєві кризи особистості, серед яких смисложиттєва криза хоча й зустрічається рідше, проте за силою впливу на людину та її подальше життя, можливою катастрофічністю наслідків - найвагоміша подія на життєвому шляху особистості.

Проблеми, пов'язані з екзистенційними аспектами існування людини у світі, завжди цікавили вчених, переважно філософів і психологів, зокрема, Е. Ліндеманн (1944) започаткував вивчення феномену кризи в психології, здійснивши аналіз особливостей переживання людьми гострого горя, його особливостей, рис і симптомів при різних варіантах перебігу цього процесу; Ф. Василюк (1981, 1984, 1995), виходячи з тлумачення процесу переживання, виокремив види кризових ситуацій і смисложиттєву кризу як особливе фундаментальне переживання, зосередившись на iї внутрішніх і зовнішніх причинах; В. Франкл (1990) вивчав проблему сенсу життя, необхідність його виявлення та здійснення, наслідки втрати (ноогенний невроз, екзистенційний вакуум); визначив екзистенційні цінності, здатні зробити життя людини осмисленим; К. АбульхановаСлавська (1991) торкнулася питання про неоптимальність життєвого сенсу та рівень психологічної ціни, що підриває його; І. Ялом (2008) аналізував проблему безглуздості життя людини у світі, який не містить сенсу; В. Чудновський $(1998,2015)$ визначив поняття сенсу життя, його роль та основні характеристики: реалістичність, конструктивність, адекватність і оптимальність; С. Мадді (2002, 2006, 2012) досліджував феномен життєстійкості, його складові та роль у подоланні стресових і кризових ситуацій («малої смерті», екзистенційного неврозу як наслідків втрати сенсу життя); Д. Леонтьєв \& I. Буровихіна (2007) вивчали тлумачення феномену «малої смерті» С. Мадді як ситуації, коли людина втрачає здатність контролювати події власного життя, необхідно переглянути життєві цінності; роль якої полягає у формуванні у людини певної життєвої 
філософіï; К. Карпінський (2008) досліджував особливості смисложиттєвої кризи (кризи безглуздості, смисловтрати, неоптимального сенсу життя) у контексті життєвих криз особистості, результатом чого став опитувальник смисложиттєвої кризи. Вітчизняна психологія більше зосереджена на вивченні й аналізі життєвих криз особистості загалом (Т. Титаренко (2007), Є. Варбан (2010), О. Гринів (2013), Г. Чуйко \& М. Комісарик (2019)).

Проте переживання людиною кризи життєвого сенсу та її наслідки, незважаючи на їх важливість для психології, дуже рідно стають предметом аналізу сучасних науковців. Тому проблема потребує подальшого вивчення з метою започаткування спроби її концептуалізації, що й зумовлює актуальність нашого дослідження, у якому ми плануємо дослідити розуміння феномену смисложиттєвої кризи, її особливостей і наслідків для людини й узагальнити результати у висновках.

Мета статті - теоретично проаналізувати розуміння смисложиттєвої кризи та життєстійкості в психології, дослідити можливий зв'язок між ними.

\section{Завдання статті}

1. Виявити особливості тлумачення феномену смисложиттєвої кризи в психології.

2. Дослідити основні проблеми та закономірності у розумінні поняття «життестійкість» і його зв'язок зі смисложиттєвою кризою.

\section{Методи дослідження}

У статті використано систему методів наукового пошуку в психології: аналіз наукової літератури з проблеми роботи, порівняння, осмислення, систематизацію й індуктивне узагальнення релевантних до теми та мети дослідження теоретичних даних. 


\section{Результати та дискусії}

Інтерес до проблеми сенсу життя філософи та психологи проявляли завжди, проте переважно імпліцитно, тоді як уперше неприховано-серйозно про важливість життєвого сенсу в організації життєвого шляху особистості та процесі життєтворення написав В. Франкл, проаналізувавши проблему сенсу життя, його знайдення та втрати (Франкл, 1990). Його думки стали певним відкриттям у психології. В. Франкл роз'яснив як те, що питання про сенс властиве самій природі людини, а прагнення його знайти - вроджена мотиваційна тенденція і ведуча сила розвитку особистості, й лише тією мірою, якою людина здійснює життєвий сенс, вона здійснює й себе; що самореалізація (як і задоволення, влада чи щастя) не може складати сенс життя людини (самореалізація - лише побічний продукт здійснення сенсу), і чим більше ми їх прагнемо і намагаємося досягти, тим менш доступними вони для нас стають (Чаплак \& Чуйко, 2017); так і обставину, що мова йде не стільки про сенс життя, скільки про сенси, індивідуальні для кожної людини у різних життєвих ситуаціях (за суттю - ситуаційні, скоріше, це життєві завдання, які потрібно вирішити, цілі, яких необхідно досягти, в конкретній ситуації: «сприйняття сенсу життя - це ... усвідомлення того, що можна зробити стосовно даної ситуації» (Чуйко, Гуляс \& Колтунович, 2009: 195)), які не винаходять, не створюють, не придумують, а виявляють (відкривають) у житті, щоб здійснити їх. Проте, за В. Франклом, мало знайти сенс життя, важливо здійснити його, не відкладаючи на потім i не втрачаючи можливостей, які передбачає ситуація (це один із сенсів, які «пропонує» людині ситуація, з якої вона має обрати той, що є «справжнім сенсом даної ситуації» (Чуйко, Гуляс \& Колтунович, 2009: 204)). Це необхідно людині, яка усвідомлює незворотність і конечність процесу життя й свого буття у світі. 3 іншого боку, людина владна обирати, чи здійснювати знайдений сенс, але будь-яке їі 
рішення - це рішення навіки, за нього вона відповідальна (перед собою, життям, Богом).

Втрачаючи сенс життя (можливість його виявити у поточній ситуації), людина, згідно В. Франкла, потрапляє у стан екзистенційного вакууму («переживання безодні»), духовного дистресу та фрустрації, що за умови значної тривалості процесу переходить у ноогенний (екзистенційний) невроз - кризу безглуздості життя. Ноогенний невроз виникає «через конфлікти між різними цінностями, на основі моральних конфліктів» (Чуйко, Гуляс \& Колтунович, 2009: 201) і виражається у внутрішній порожнечі духовного життя людини (Чуйко, Гуляс \& Колтунович, 2009: 202), апатії, депресії, втраті інтересу до життя, прагненні до мінімізації внутрішнього напруження. За суттю, людина повністю виключається з потоку життя.

I. Ялом певною мірою полемізує з В. Франклом, визначаючи основні екзистенційні даності, серед яких - безглуздість: ми шукаємо і реалізуємо сенс життя, але у всесвіті без сенсу, - та пропонуючи свій погляд на дії, здатні зробити життя людини осмисленим (Ялом, 2008) (тоді як, за В. Франклом, сенси знаходяться саме в ноетичному вимірі існування людини).

Проаналізувавши теорії та думки інших мислителів, близьких I. Ялому за духом, він приходить до висновку, що «питання про сенс життя - найсуттєвіше», але жодному великому мислителю упродовж усієї історії не вдалося задовільно розв'язати загадку сенсу життя (Ялом, 2008) і що криза життєвого сенсу змушує людину зіткнутися 3 «екзистенційною ситуацією і відкриває їй очі на ілюзорність багатьох смислових систем» (Чуйко \& Комісарик, 2019).

Так, А. Камю турбувала проблема, чи варто жити далі, повністю впевнившись у безглуздості людського життя; К.-Г. Юнг тлумачив невроз як «страждання душі, яка не знаходить свого сенсу», В. Франкл, вважаючи відсутність сенсу «першорядним екзистенційним стресом», екзистен- 
ційний невроз розумів як «синонім кризи безглуздості»; С. Мадді описував екзистенційний невроз (когнітивною складовою якого $\mathrm{\epsilon}$ «безглуздість»), що проявляється як «нездатність перейнятися істинністю, важливістю, корисністю чи цікавістю» будь-чого, у чому людина бере участь (чи має такий намір) (Ялом, 2008). Власне, це нездатність побачити дрібку сенсу ні в чому.

Для самого I. Ялома проблема набула такої форми: «як істота, яка потребує сенсу, знаходить сенс у всесвіті, що сенсу не має? ( (Ллом, 2008). Згідно з екзистенційною точкою зору, світ випадковий: усе, що є, могло бути інакшим, ніякого смислу чи замислу всесвіту не існує, за винятком тих, які створює сам індивід. Адже, за І. Яломом, людина потребує сенсу, який підтримує її життя, а «відсутність сенсу, цілей, цінностей та ідеалів викликає значні страждання», що в гострій формі можуть привести людину до рішення накласти на себе руки (Ялом, 2008).

I. Ялом цитує В. Франкла, який цілком логічно і зрозуміло пояснює, що ніхто не може постійно бути успішним чи досягати бажаного, проте можна «рухатися в правильному напрямку», «знаходячи своїм талантам найбільш конструктивне, продуктивне i творче застосування», у чому полягає «головне значення життя» $\mathrm{i}$ «єдино можлива відповідь на екзистенційний невроз», але помічає, що безглуздість дуже часто не є первинною чи елементарною проблемою, а складною чи похідною, і врешті виявляє, що «ми сприймаємо речі як безглузді, тільки коли знаходимося в космічній перспективі», дивлячись на себе, своє життя і оцінюючи його зі сторони («галактичним поглядом») (Ялом, 2008). I тому «безглуздість - це переживання, і хоча воно так полонить, що, здається, робить безглуздим усе в минулому і майбутньому, як і в сьогоденні, так діяти воно може, лише коли ми дивимося на своє життя з галактичної точки зору» (Ялом, 2008) (ідеться про самотрансценденцію та самовідсторонення - найбільш значущі риси людини, за В. Франклом), яке дає спостерігачу більшу об’єктивність, 
але, при зловживанні ними, «відбирає у життя вітальність» (життєвість). Тільки з цієї точки зору речі, за І. Яломом, повинні мати сенс, щоб бути значущими для нас. У інших наших станах речі мають значення для нас просто «тому, що вони мають значення» і їм не обов' язково нести сенс, який би робив їх значущими. «Галактичному» погляду та безглуздості всесвіту Ялом певною мірою протиставляє «земний сенс» ( «сенс мого життя», особисте відчуття сенсу, яке «не має в основі ніякого космічного смислового фундаменту»), що включає мету: людина, яка володіє відчуттям сенсу, сприймає життя як таке, що володіє якоюсь метою чи функцією, яку потрібно реалізувати, певною ведучою задачею чи завданнями для виконання (Ялом, 2008).

Аналізуючи твори Ж⿱.-П. Сартра і А. Камю, І. Ялом виявляє, що вони суперечать їх філософським поглядам, відкриваючи, що насправді для них було важливо, щоб людина усвідомила: вона повинна створити власний сенс і потім повністю присвятити себе його втіленню. Етика Ж․-П. Сартра, згідно І. Ялома, «потребує стрибка у залученість (включеність)»: «у цьому єдиному пункті сходяться багато західних теологічних і естетичних екзистенційних систем: зануритися в потік життя - ие добре і правильно» (Ялом, 2008).

Розглядаючи «дії, або стани дії, які дають людині відчуття життєвої мети», «представляються правильними, добрими», приносять внутрішнє задоволення i «не потребують виправдання за допомогою будь-якої іншої мотивації» (Ялом, 2008) (за суттю, це аналог екзистенційних цінностей В. Франкла, що дозволяють зробити життя осмисленим), І. Ялом виокремлює такі: альтруїзм; відданість справі; творчість; гедонізм і самоактуалізацію. Останні два сенси від попередніх відрізняються тим, що «виражають турботу про власне «Я», тоді як решта - пов'язані з глибинною жагою людини перевершити себе та спрямуватися до чогось чи когось поза чи «вище» за саму себе». Проте, 
різні смислоутворюючі види життєвої активності не є взаємовиключними (Ялом, 2008).

За С. Мадді, людина, стикаючись зі стресами, постійно вирішує (незалежно, чи усвідомлює вона це) рухатися їй до майбутнього (сприймаючи обставини як життєвий виклик) чи відступати до минулого (уникаючи, щоб захистити статус quo). Але для того, щоб рости і розвиватися, людина повинна вибрати майбутне, навіть думаючи, що це провокує тривогу внаслідок можливої зустрічі з несподіваним. Зустрічі з цією тривогою та процес зростання вимагають мужності, складовою якої виявиться характеристика особистості, яку I. Ялом вважав визначальною у пошуку життєвого сенсу, - залученість, що є складовою іншого феномену - життєстійкості (Maddi, 2006).

С. Мадді вважав життєстійкість (hardy, hardiness - витривалість, відвага, зухвалість, міць, сміливість) синонімом екзистенційної мужності («мужності жити», за П. Тілліхом), пояснюючи, що цей феномен з'явився як модель установок і стратегій, які роблять можливим перетворити стресові обставини життя з потенційних загроз нещастя на можливості особистісного зростання. Зћиттєстійкість пов'язана з мотивацією вчитися ефективній i адаптивній поведінці у стресі. Існують три складові життєстійкості це установки залученості, контролю та прийняття виклику (Maddi, 2002; Puri, 2016).

Виклик (challenge) означає бажання постійно вчитися на власному досвіді (як позитивному, так і негативному) замість того, щоб намагатися чинити завжди безпечно, уникаючи невпевненості та потенційних загроз. Інша складова витривалості - залученість (commitment) - це схильність людини бути прихильною до людей, речей і контекстів, утягнутою в життєві події, взаємодіяти з ними, що передбачає наявність переконання (віри), що незалежно від того, наскільки все погано, важливо залишатися включеним у те, що відбувається, що б не сталося, розв'язувати життєві завдання, а не віддалятися, занурюючись у безпристрас- 
ність і відчуження, які б стресові події не відбулися. Третя складова життєстійкості - контроль (control) за подіями життя, який включає зусилля впливати на результат (наслідки) того, що продовжує відбуватися навколо людини, i веде до віри, що, не зважаючи ні на що, варто постійно намагатися перетворити стреси з потенційних катастроф на можливості особистісного зростання. Марна трата часу дозволити собі зануритися в безнадію та пасивність, вважає С. Мадді, а вчитися можна як на успіхах, так і на невдачах (Lindsey, 1992; Maddi, 2002; Maddi, Matthews, Kelly et al., 2006; Puri, 2016).

Люди, сильні в усіх трьох установках життєстійкості, згідно С. Мадді, схильні: 1) бачити життя як постійно мінливий феномен, що спонукає їх вчитися і змінюватися (кидати виклик); 2) думати, що завдяки цьому процесу розвитку вони можуть працювати над змінами в манері поведінки, засвоюючи досвід здійснення контролю; 3) розподіляти ці зусилля і навчатися завдяки підтримці значущих інших і соціальних інститутів у житті (залученість) (Puri, 2016). Разом ці складові життєстійкості «формують особистісний стиль, який є поєднанням пізнання, емоцій і поведінки, метою якого є не лише виживання, але збагачення життя в напрямку розвитку» (Lindsey, 1992). Установки життєстійкості сприяють усвідомленню того, що людина формулює сенс життя для себе за допомогою рішень, які приймає, і що постійний вибір майбутнього, всупереч тривозі й невпевненості, веде до найяскравішого (насиченого) життя (Maddi, 2002).

С. Мадді використовує також поняття «маленькой слерmi», яка відбувається щоразу, коли людина опиняється у важких життєвих обставинах, які не в змозі контролювати чи змінити, що змушують людину «переглянути їі систему конструктів людина-і-світ» (Чуйко, Гуляс \& Колтунович, 2009: 291). Для ситуації «малої смерті» характерне почуття смисловтрати (Леонтьев, 2007). За С. Мадді, «ми стикаємося зі смертю в невеликому масштабі завжди, коли 
закінчується щось, закінчення чого ми не хотіли б ... коли нас гнітить брак часу і сил, щоб зробити все, до чого ми щиро прагнемо ... або коли життя монотонне... »; при цьому людина відчуває страх через непідвладність і неконтрольованість небажаних і незалежних від неї подій, «через безглуздість життя» (Леонтьєв, 2007). Цілком закономірно, що такі ситуації нагадують про фізичну смерть: адже вони є погрозами смерті психологічної і можуть призвести до хронічного стану безглуздості та безсилля, який С. Мадді назвав екзистенціальною хворобою (Леонтьєв, 2007).

Зазначимо, що для С. Мадді, як і для I. Ялома, безглуздість виявляється пов'язана з марнуванням часу і незалученістю до буденного життєвого процесу виживання, тоді як залученість $\mathrm{\epsilon}$ «головною терапевтичною відповіддю на безглуздість» (Ялом, 2008).

Екзистенційний невроз С. Мадді описує як «стан, у якому внаслідок відсутності сенсу життя з' являється нудьга, загальна незацікавленість і чітко виражена пасивність у ситуаціях, коли потрібно сформувати власну думку... зробити свідомий вибір, прийняти самостійне рішення» (Чуйко, Гуляс \& Колтунович, 2009: 300). І. Ялом виокремлює три клінічні форми «екзистенційного захворювання» (термін С. Мадді для позначення проникаючої всюди у життя безглуздості): крусадерство, нігілізм і вегетативність (Ялом, 2008).

Позитивну роль «малої смерті» С. Мадді вбачає у сприянні розвитку особистості, розумінні нею обмеженості свого контролю над життєвими ситуаціями, використанні більше часу й усіх своїх можливостей для досягнення найбільш значущих життєвих цілей, замість їх безглуздого марнування. Зіткнення з «малою смертю» сприяють формуванню життєвої філософії особистості: позитивної чи негативної. Жћиттєва філософія, яка багато в чому визначається стилем батьківського виховання, - це злагоджена система поглядів людини на себе, на людство загалом, на суспільство та їх взаємозв' язок; очікувань, уподобань і цін- 
ностей. Саме життєва філософія визначає спрямованість і сенс життєдіяльності людини (Леонтьєв, 2007). Позитивна життєва філософія формується, коли людина розуміє, що багато з подій її життя - це зіткнення з «малою смертю», тому необхідно навчитися справлятися з ними, зокрема, цьому сприяє така особистісна диспозиція, як життєстійкість, що «допомагає людині сміливо дивитися в обличчя екстремальним обставинам і знаходити в них користь» (Чуйко, Гуляс \& Колтунович, 2009: 293). Негативна життєва філософія розвивається у людей, які або не здатні визнати, що певні життєві події є зіткненням зі смертю, або, розуміючи це, лякаються перешкод, суб'єктивно вважаючи їх нездоланними, а свою здатність справитися з ними недостатньою, переживають почуття відчаю, песимізму та безглуздості життя (Чуйко, Гуляс \& Колтунович, 2009).

За С. Мадді, людина постійно змушена приймати рішення, спрямовані або в бік минулого, якщо людина відчуває страх змін і прагне зберегти звичний спосіб існування (постійний вибір минулого приводить до екзистенційного неврозу чи хвороби - відчуття відсутності сенсу життя), або в напрямку майбутнього (спираючись на життєстійкість), якщо людина автентична, володіє внутрішнім життям, довіряє собі, впевнена у власній цінності та життєздатності, відчуває інтерес до нового життєвого досвіду, прагне розширити звичну картини світу, знаходячи індивідуальні (особистісні) сенси. Щоб бути відважною, людині необхідна віра в себе чи впевненість у своїй цінності та здатності жити. Крім того, у людини мають бути добре розвинуті когнітивні функції, що створюють сенс, який Мадді вважає вищим інтегративним началом особистості: символізація, уява (уявлення) та судження (Чуйко, Гуляс \& Колтунович, 2009).

Те, що В. Франкл назвав переживанням екзистенційного вакууму з відповідними наслідками, I. Ялом - кризою сенсу чи кризою безглуздості, а С. Мадді - «малою смертю» чи екзистенційним неврозом, у К. Карпінського отримує 
назву смисложиттєвої кризи, проте в психології традиційно вважається, що науковий інтерес до дослідження переживання кризи бере початок від роботи Е. Ліндеманна, присвяченої аналізу переживання гострого горя людьми, які втратили близьких через смерть від хвороби чи катастрофи (пожежі), та близькими тих, хто служить у збройних силах. Учений не лише описав відмітні риси переживання горя, але й симптоми, специфічно характерні та визначальні для нормального ходу цього процесу: 1) соматичний (тілесний) дистрес; 2) поглиненість образом покійного; 3) почуття провини, втрата теплоти у стосунках з іншими людьми; 4) ворожі реакції, настільки незрозумілі для пацієнтів, що витлумачуються ними як наближення божевілля; 5) втрата зразків поведінки - виявляються як ознаки горя: хворі не бажають, щоб їх турбували інші люди, тоді як друзі та близькі роблять зусилля, щоб зберегти стосунки; 6) не такий помітний, як інші: поява рис (характеристик, манери поведінки) померлого в поведінці потерпілих, які виявляє сама людина (Lindemann, 1944). Е. Ліндеманн також зазначив, що порушення у цьому процесі (спотворена, не розв'язана реакція переживання) призводить до важких наслідків, яким, за І. Яломом, відповідає почуття екзистенційної самотності (ізольованості від життя та світу).

Вивчаючи смисложиттєву кризу, К. Карпінський зазначає, що в психології проблема життєвої кризи аналізується переважно у віковому аспекті, де увага акцентується на дитячих кризах, які «провокуються переважно зовнішніми чинниками», рідше - на кризах зрілого періоду життя людини, які «максимально залежать від особистості», та в персонологічному контексті, де криза сенсу життя розглядається як системна криза особистісного буття, що вражає «ядерні» структури внутрішнього світу особистості й паралізує її життєдіяльність (крім того, вчений зазначає, що вивченням смисложиттєвої кризи займаються психологія життєвого шляху та кризова психологія) (Карпинский, 2008).

(C) Halyna Chuiko 
К. Карпінський також виявляє суттєві відмінності між цими трактуваннями кризи: 1) з точки зору детермінації, смисложиттєва криза трактується як екзогенна в персонологічному та як ендогенна - у віковому підході; 2) для персонології така криза є ненормативною подією (випадає на долю не кожної людини, не «прив'язана» до певного віку, iï неможливо передбачити); у віковому підході - це нормативна подія життя кожної людини у певному віці, кризу можна прогнозувати та попередити її можливі негативні наслідки: криза сенсу життя - це обов'язковий етап, без проходження якого неможливий прогресивний стабільний розвиток і досягнення справжньої особистісної зрілості; 3) з погляду нормальності, в персонологічному підході смисложиттєва криза - явище зі сфери психопатології (це психотравмуючий стан, що призводить до дезадаптації та деформації особистості, вона «дезорганізує нормальну життєдіяльність і невротизує особистість» (Карпинский, 2008) (тобто, наслідки їі переважно негативні)), у віковому - це природне явище, феномен нормального розвитку людини, що не виходить за межі норми, й абсолютно необхідне для нормального особистісного зростання; навпаки, відсутність, несвоєчасність або надмірна тривалість кризи може інтерпретуватися як ознака спотворення або затримки розвитку особистості (така криза переважно конструктивна).

За В. Чудновським, сенс життя - це «психологічний феномен, суть якого - відображення у свідомості суб’єкта особливостей ієрархії цільових установок його життя і діяльності, що стали для нього життєво значимою цінністю надзвичайно високого порядку» (Чудновский, 2015), він дає людині змогу сприймати «конкретну ситуацію у світлі цілісного «життєвого простору» і відповідно до цього намічати та реалізовувати власні ідеї ... складність віднайдення сенсу життя в тому, щоб виявити його серед множини проявів безглуздості життя ... це і процес «вибудовування» людиною «лінії» своєї долі» (Чудновский, 1998). Основними 
характеристиками сенсу життя, за В. Чудновським, є реалістичність - відповідність сенсу наявним, об'єктивним умовам, необхідним для його реалізації, та індивідуальним можливостям людини, і конструктивність, що відображає ступінь його впливу (позитивного чи негативного) на процес становлення особистості й успішність їі діяльності. Разом вони складають адекватнісmь сенсу життя як одну з базових його характеристик.

Зазначимо, що, на нашу думку, сенс не завжди володіє для людини цією мотивуючою тенденцією (силою), залежно від його змісту, з одного боку, та світосприйняття людини (зокрема, вона може вірити у наперед визначеність, приреченість чи долю, або у цілковиту випадковість усього; зрештою, навіть не цікавитися проблемою виявлення життєвого сенсу), з іншого, - він може сприйматися нею як даність; по-друге, пригадаймо В. Франкла: виявивши сенс свого життя, людина вирішує, буде його реалізовувати, чи ні (i «ні» - це її вибір).

Більш грунтовно обставини, що спричиняють «неоптимальність» сенсу, аналізує К. Абульханова-Славська, згідно з якою сенс життя втрачається людиною «через непропорційність тих психічних чи особистісних затрат, тієї «ціни», яку особистість платить за свої реальні досягнення» (Абульханова-Славская, 1991). Мова йде про дію «своєрідного психологічного закону: надто висока психологічна ціна, витрачена на життєві досягнення, знижує мотивацію, домагання та підриває сенс життя. Можливостям особистості повинна бути пропорційна міра зусиль, дій, затрат, за якої особистість відчувала б справжню за-

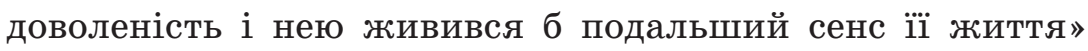
(Абульханова-Славская, 1991). Проте, коли «ціна» надто мала, а успіх приходить без усяких зусиль з боку особистості, то вона також перестає відчувати задоволення, а це, у свою чергу, руйнує сенс її життя.

Зазначимо, що, за Ф. Василюком, «смисложиттєва криза - це внутрішня криза (внутрішня критична ситуа- 
ція), хоча причини їі можуть лежати і поза людиною, зовні, проте відповідальність за неї людина бачить за собою (своєю реакцією на зовнішні умови)» (Василюк, 1981). Іншими словами, у переживанні смисложиттєвої кризи важко виявити і відокремити домінування внутрішніх чи зовнішніх причин, оскільки у будь-якому випадку вона переживається суб’єктивно (внутрішньо).

Здійснивши аналіз різних психологічних підходів до розуміння смисложиттєвої кризи, К. Карпінський нарешті пропонує таке узагальнене їі визначення: «криза сенсу життя - це різновид ціннісно-смислової кризи, пов' язаний із дезінтеграцією, дестабілізацією, дезорганізацією або з елементарною несформованістю в особистості ієрархії смисложиттєвих цінностей, які функціонують як провідні інстанції смислової регуляції та джерела утворення сенсу життєвого шляху» (Карпинский, 2008), - хоча залишається не цілком зрозумілим, чому криза сенсу життя визначається і розуміється винятково через кризову ситуацію зі смисложиттєвими цінностями, навіть зважаючи на те, що вони можуть бути джерелом сенсу (хоча, можливо, і навпаки: те, в чому ми бачимо сенс, ми починаємо цінувати, зводячи на вершину суб’єктивної ціннісної ієрархії).

Ф. Василюк також виокремив два роди кризових ситуацій за ступенем можливості реалізації внутрішньої необхідності життя: криза першого роду здатна серйозно ускладнювати реалізацію життєвого сенсу, однак ще зберігає можливість відновлення перерваного кризою життєвого шляху; із цієї кризи людина здатна вийти відносно безболісно (майже за Ф. Ніцше: «...що нас не вбиває - робить нас сильнішими»), зберігши хоча б в основному свій життєвий задум і самототожність; кризова ситуація другого роду (власне криза, або смисложиттєва криза) робить реалізацію життєвого сенсу зовсім неможливою, внаслідок переживання цієї кризи стається «метаморфоза особистості», яка змушена прийняти новий життєвий сенс і відповідні йому цінності, стратегію життя, новий «образ-Я» (Ва- 
силюк, 1984). Учений зазначає, що така ситуація не може бути вирішена ні зовнішньою, ні внутрішньою діяльністю, iii потрібно пережити, долаючи «неможливість» (безглуздість, станами якої є «розпач, безнадія, нездійсненність, неминучість тощо») "у відновленні або породженні усвідомленості життя» (Василюк, 1984). При цьому вчений витлумачує процес переживання (типами якого є гедоністичне, реалістичне, ціннісне та творче переживання) як «боротьбу проти неможливості жити ... проти смерті всередині життя», за те, що є «важливим, значимим, принципово необхідним для людини» (Василюк, 1995).

Саме питання про сенс життя з'являється i починає турбувати людину ( ннавіщо я жила, для якої мети я народилася...») не тоді, коли, на її думку, життя склалося, як бажалося, вона - щаслива, все - переважно благополучно, а в той момент, коли все чи майже все, в оцінці людини, негаразд, і саме таку життєву ситуацію можна вважати переломною у переході до відчуття кризи сенсу життя, якщо відповідь на це важливе запитання не задовольнить людину. В цьому випадку 3. Фрейд був не такий далекий від істини, стверджуючи, що пошук сенсу життя є симптомом хвороби.

На нашу думку, кризова ситуація може тривати довго чи коротше, об'єктивно чи ні (лише у душевному світі самої людини), проте для особистості, яка їі переживає, криза тягнеться надто довго у будь-якому разі, більш того, особливо турбує те, що невідомо, коли вона скінчиться і чи скінчиться взагалі, з одного боку, а з іншого - людина не може уявити собі, що робити, як вийти з кризи і що чекати у майбутньому, оскільки сподіватися на щось імовірно-конкретне вона не наважується (людина не знає, що їй робити в цей момент і, тим більше, далі). Людина розуміє, що втрачені не лише колишне життя, її світ, життєві цінності та сенс без можливості відновлення чи компенсації втрати, але й частина себе, яка нерозривно пов'язується з утраченим; що нічого всередині їі душі не залишилося 
вільним від цієї втрати, страшної своєю незворотністю та некомпенсованістю нічим, навіть на ймовірнісному рівні. Смисложиттєва криза - це втрата саме того, що складало фундамент буття людини (того, заради чого вона жила та, водночас, навіщо).

Криза переживається як конфлікт між бажаним і можливим (як внутрішньо, так і зовнішньо), причому проблема полягає не у браку життєвої енергії, а у відсутності визначеності напрямку їі застосування (людина не уявляє собі, як досягти бажаного). Проте відчуття кризи лише посилюється, якщо людина бачить, яким шляхом їй треба йти, але розуміє, що ним скористатися з різних причин вона не може. I єдине, що вдається, - змиритися і зайняти певну позицію стосовно того, що відбувається, прийняти як даність, принаймні, частку критичної ситуації, бо кожна спроба перебороти її (справитися з нею) обертається новим емоційним зривом і психологічним крахом. Тож варто, скориставшись філософською мудрістю, прийняти те, що змінити неможливо. Можливість справитися з кризовою ситуацією, перебороти її з'являється лише тоді, коли людина адаптується до неї настільки, що сприймає їі як звичну (нормальну) життєву ситуацію.

\section{Висновки}

Психологічний феномен смисложиттєвої кризи розглядають як переломний і поворотний момент у житті людини, пов'язаний із проблемами втрати сенсу життя, блокування смислотворення та нівелювання екзистенційних цінностей людини, який зумовлює грунтовні, непрогнозовані, переважно негативні наслідки.

Смисложиттєва криза - це життєва ситуація гострої i / чи тривалої неможливості реалізації людиною сенсу їі життя, що стає суб'єктивно нездоланною перешкодою на життєвому шляху особистості, причиною чого, зазвичай, є внутрішній конфлікт між бажаним (що представляється людині надважливим й абсолютно необхідним для її жит- 
тя) і можливим (відсутністю внутрішніх і зовнішніх передумов для реалізації життєвого сенсу).

Жћиттєстійкість як особистісну диспозицію вважаємо здатною сприяти подоланню людиною смисложиттєвої кризи, винесенню життєвих уроків з їх переживання, що дає змогу мінімізувати її негативні наслідки та виявити у ній позитивний життєстверджувальний аспект.

Перспективу подальшого дослідження вбачаємо в аналізі особистісних чинників переживання смисложиттєвої кризи.

\section{Література}

Абульханова-Славская К. А. Стратегия жизни. Москва : Мысль, 1991. 299 c.

Варбан Є. О. Жииттєва криза: поняття, концепції та прояви. Проблели сучасної психологї: Збірник наукових пращь КПНУ ілені Івана Огієнка, Інституту психологї іл. Г. С. Костюка АПН Украӥни. 2010. Вип. 8. С. 120-133.

Василюк Ф. Е. Психологический анализ преодоления критических ситуаций: автореф. дис. ... канд. психол. наук: спец. 19.00.01 / МГУ. Москва, 1981. 18 с.

Василюк Ф. Е. Психология переживания (анализ преодоления критических ситуаций). Москва : Изд-во Моск. ун-та, 1984. 200 с.

Василюк Ф. Е. Типология переживания различных критических ситуаций. Психологический журнал. 1995. Т. 16. № 5. С. 104-114.

Гринів О. Конструктивне подолання життєвих криз як детермінанта психологічного благополуччя особистості в ранній дорослості. Психологія особистості. 2013. № 1 (4). С. 173-179.

Карпинский К. В. Опросник смысложизненного кризиса: монография. Гродно : ГрГУ, 2008. 108 с.

Леонтьев Д. А., Буровихина И. А. Фасилитирующие эффекты опыта «малой смерти». Третья всероссийская научно-практическая конферениия по экзистенииальной психологии: материаль сообщений / Под ред. Д. А. Леонтьева. Москва : СМЫСЛ, 2007. С. 140145. URL : http://institut.smysl.ru/article/smdie.php.

Титаренко Т. М. ЖКиттєві кризи: технології консультування. Ч. 1. Київ : Главник, 2007. 144 с.

Франкл В. Человек в поисках смысла: Сборник / Общ. ред. Л. Я. Гозмана и Д. А. Леонтьева. Москва : Прогресс, 1990. 368 с.

Чаплак Я. В., Чуйко Г. В. Сенс життя як орієнтир на життєвому шляху людини. Психологічний часопис: Збірник наукових праць. 2017. № 1 (5). Вип. 5. С. 100-111. URL : http://ua.appsyjournal.com/. 
Чудновский В. Э. Проблема оптимального смысла жизни. Психология и школа: научно-летодический журнал. 2015. № 1. С. 100-117. URL : http://akme31.narod.ru/1.html.

Чудновский В. Э. Смысл жизни и судьба человека. Общественные науки и совреленность. Культура. 1998. № 1. С. 175-183. URL : http://ecsocman.hse.ru/data/154/128/1218/017Chudnovskij.pdf.

Чуйко Г. В., Гуляс I. А., Колтунович Т. А. Екзистенційна психологія: навч. посіб. Чернівці : Прут, 2009. 308 с.

Чуйко Г. В., Комісарик М. І. Проблема життєвих криз особистості у психології. Психологічний часопис: Збірник наукових праць. 2019. № 1 (21). С. 41-56. doi.org/10.31108/1.2019.1.21.3.

Ялом И. Экзистенциальная психотерапия. Москва : РИМИС, 2008. $608 \mathrm{c}$.

Lindemann, E. (1944). Symptomatology and management of acute grief. American Jornal of Psychiatry, 101 (2), 141-148. DOI 10.1176/ ajp.101.2.141.

Lindsey, E., \& Hills, M. (1992). An analysis of the concept of hardiness. The Canadian journal of nursing research, 24, Issue 1, 39-50. Retrieved from http://cjnr.archive.mcgill.ca/article/view/1141.

Maddi, S. R. (2006). Hardiness: the courage to grow from stresses. The Journal of Positive Psychology, 1, Issue 3, 160-168. doi.org/10.1080/ 17439760600619609.

Maddi, S. R., Matthews, M. D., \& Kelly, D. R. (2012). The role of hardiness and grit in predicting performance and retention of USMA cadets. Military psychology, 24, Issue 1, 19-28. doi.org/10.1080/08995605. 2012.639672.

Maddi, S. R. (2002). The story of hardiness: twenty years of theorizing, research and practice. Consulting psychology journal: practice and research, 54 (3), 173-185. doi.org/10.1037/1061-4087.54.3.173.

Puri, R. (2016). Does Hardiness Improve Resilience? International Journal of Engineering Technology Science and Research, 3, Issue 4, 47-49. Retrieved from http://www.ijetsr.com/images/short_pdf/ 1460797113_iciresm275_ijetsr.pdf.

\section{References}

Abul'hanova-Slavskaja, K. A. (1991). Strategija zhizni [Life strategy]. Moskva : Mysl' [in Russian].

Varban, Ye. O. (2010). Zhyttieva kryza: poniattia, kontseptsii ta proiavy [Life crisis: the notion, the concepts and manifestations]. Problemy suchasnoi psyhologii - Problems of modern psychology: Collection of research papers of Kamianets-Podilskyi National Ivan Ohiienko University, G. S. Kostiuk Institute of Psychology of NAES of Ukraine, 8, 120-133 [in Ukrainian]. 
Vasiljuk, F. E. (1981). Psihologicheskij analiz preodolenija kriticheskih situatsij [Psychological analysis of overcoming critical situations]. Extended abstract of candidate's thesis. Moskva : MGU [in Russian].

Vasiljuk, F. E. (1984). Psihologija perezhivanija (analiz preodolenija kriticheskih situatsij) [Psychology of experiencing (analysis of overcoming critical situations )]. Moskva : Izd-vo Mosk. un-ta [in Russian].

Vasiljuk, F. E. (1995). Tipologija perezhivanija razlichnyh kriticheskih situatsij [Typology of experiencing various critical situations]. Psihologicheskij zhurnal - Psychological Journal, 5, Vol. 16, 104-114 [in Russian].

Hryniv, O. (2013). Konstruktyvne podolannia zhyttievykh kryz yak determinanta psykholohichnoho blahopoluchchia osobystosti v rannii doroslosti [Constructive overcoming of life crises as a determinant of psychological well-being of a personality in early adulthood]. Psykholohiia osobystosti - Psychology of personality, 1 (4), 173-179 [in Ukrainian].

Karpinskij, K. V. (2008). Oprosnik smyslozhiznennogo krizisa [Questionnaire on the meaning of life crisis ]. Grodno : GrGU [in Russian].

Leont'ev, D. A., \& Burovihina, I. A. (2007). Fasilitirujushchie jeffekty opyta «maloj smerti» [Facilitating effects of the «small death» experience]. D. A. Leont'ev (Ed.). Tret'ja vserossijskaja nauchno-prakticheskaja konferentsija po jekzistentsial'noj psihologii - The Third All-Russian Scientific and Practical Conference on Existential Psychology: Proceedings of the conference (pp. 140-145). Moskva : SMYSL. Retrieved from http://institut.smysl.ru/article/smdie.php [in Russian].

Tytarenko, T. M. (2007). Zhyttievi kryzy: tekhnolohii konsultuvannia [Life Crises: Technology of Counseling]. P. 1. Kyiv : Glavnyk [in Ukrainian].

Frankl, V. (1990). Chelovek $v$ poiskah smysla [Man in search of meaning]. L. Ja. Gozman, D. A. Leont'ev (Eds.). Moskva : Progress [in Russian].

Chaplak, Ya. V., \& Chuiko, H. V. (2017). Sens zhyttia yak oriientyr na zhyttievomu shliahu liudyny [The meaning of life as a landmark on the human's life way]. Psykholohichnyi chasopys - Psychological journal, 1 (5), Issue 5, 100-111. Retrieved from http://ua.appsyjournal. com/ [in Ukrainian].

Chudnovskij, V. Je. (2015). Problema optimal'nogo smysla zhizni [The problem of the optimal meaning of life]. Psihologija i shkola - Psychology and school: scientific and methodical journal, 1, 100-117. Retrieved from http://akme31.narod.ru/1.html [in Russian].

Chudnovskij, V. Je. (1998). Smysl zhizni i sud'ba cheloveka [The meaning of life and the fate of man]. Obshchestvennye nauki i sovremennost'. Kul'tura - Social sciences and modernity. Culture, 1, 175-183. Re- 
trieved from http://ecsocman.hse.ru/data/154/128/1218/017Chud novskij.pdf [in Russian].

Chuiko, H. V., Hulias, I. A., \& Koltunovych, T. A. (2009). Ekzystentsiina psykholohiia [Existential psychology]. Chernivtsi : Prut [in Ukrainian].

Chuiko, H.V., \& Komisaryk, M. I. (2019). Problema zhyttievykh kryz osobystosti u psykholohii [The problem of life crises of personality in psychology]. Psykholohichnyi chasopys - Psychological journal, 1 (21), 41-56. doi.org/10.31108/1.2019.1.21.3 [in Ukrainian].

Jalom, I. (2008). Jekzistentsial'naja psihoterapija [Existential psychotherapy]. Moskva : RIMIS [in Russian].

Lindemann, E. (1944). Symptomatology and management of acute grief. American Jornal of Psychiatry, 101 (2), 141-148. DOI 10.1176/ ajp.101.2.141.

Lindsey, E., \& Hills, M. (1992). An analysis of the concept of hardiness. The Canadian journal of nursing research, 24, Issue $1,39-50 . \mathrm{Re}-$ trieved from http://cjnr.archive.mcgill.ca/article/view/1141.

Maddi, S. R. (2006). Hardiness: the courage to grow from stresses. The Journal of Positive Psychology, 1, Issue 3, 160-168. doi.org/10.1080/ 17439760600619609.

Maddi, S. R., Matthews, M. D., \& Kelly, D. R. (2012). The role of hardiness and grit in predicting performance and retention of USMA cadets. Military psychology, 24, Issue 1, 19-28. doi.org/10.1080/08995605. 2012.639672 .

Maddi, S. R. (2002). The story of hardiness: twenty years of theorizing, research and practice. Consulting psychology journal: practice and research, 54 (3), 173-185. doi.org/10.1037/1061-4087.54.3.173.

Puri, R. (2016). Does Hardiness Improve Resilience? International Journal of Engineering Technology Science and Research, 3, Issue 4, 47-49. Retrieved from http://www.ijetsr.com/images/short_pdf/ 1460797113_iciresm275_ijetsr.pdf.

\section{Чуйко Галина. Криза сенсу як переломний момент життя людини}

\section{АНОТАЦІЯ}

Статтю присвячено теоретичному аналізу феномену смисложиттєвої кризи, їі особливостей, проявів і наслідків для життя особистості, а також життєстійкості як можливого бар'єру гострому і тривалому переживанню людиною кризи сенсу життя (аналогічно до подолання стресового стану та перетворення його на можливість винесення уроків із його перебігу й особистісного зростання).

Зазначено, що смисложиттєва криза хоча й зустрічається рідше за інші кризи особистості, проте переживається особливо гостро, а 
за силою впливу на людину, їі подальше життя та можливою катастрофічністю наслідків - це найвагоміша подія на життєвому шляху особистості.

Проаналізовано погляди на смисложиттєву кризу та ії специфіку відомих зарубіжних (Ф. Е. Василюк, К. В. Карпинский, С. Мадді, В. Франкл, В. Э. Чудновский, І. Ялом та ін.) психологів. Зазначено, що В. Франкл назвав ії переживанням екзистенційного вакууму з відповідними наслідками, І. Ялом - кризою сенсу, або кризою безглуздості, С. Мадді - «малою смертю», чи екзистенційним неврозом, К. В. Карпінський використовує назву "смисложиттєва криза», під якою розуміє смислову кризу в розвитку особистості, що блокує, насамперед, смислову регуляцію і процеси смислотворення індивідуального життєвого шляху та визначає ії основні прояви, причиною чого є проблеми з пошуком чи реалізацією сенсу життя особистості.

Виявлено, що смисложиттєва криза переживається людиною як тривалий і / чи гострий внутрішній конфлікт між бажаним (життєво необхідним, надважливим для неї) та об'єктивно можливим. При цьому людина, навіть уявляючи шлях досягнути бажаного, не завжди може ним скористатися, що змушує ії прийняти все, як є, і намагатися справитися із ситуацією. У переживанні смисложиттєвої кризи неможливо відділити внутрішні та зовнішні ії причини, оскільки вона завжди переживається на суб'єктивному рівні.

Зроблено висновок, що життєстійкість може бути використана для подолання смисложиттєвої кризи особистості, мінімізуючи ії негативні наслідки та перетворюючи на можливість розвитку особистості шляхом засвоєння життєвих уроків і знаходження нового особистісного життєвого сенсу.

Ключові слова: смисложиттєва криза, життєстійкість, сенс життя, залученість, екзистенційний невроз, криза безглуздості.

\section{Чуйко Галина. Кризис смысла как переломный момент жизни человека}

\section{АННОТАЦИЯ}

Статья посвящена теоретическому анализу феномена смысложизненного кризиса, его особенностей, проявлений и последствий для жизни личности, а также жизнестойкости как возможного барьера для острого и длительного переживания человеком кризиса смысла жизни (аналогично преодолению стрессового состояния и превращению его в возможность извлечения уроков из его течения и личностного роста).

(C) Halyna Chuiko 
Отмечено, что смысложизненный кризис хотя и встречается реже других кризисов личности, но переживается особенно остро, а по силе воздействия на человека, его дальнейшую жизнь и возможной катастрофичности последствий - это весомое событие на жизненном пути личности.

Проанализированы взгляды на смысложизненный кризис и его специфику известных зарубежных (Ф. Е. Василюк, К. В. Карпинский, С. Мадди, В. Франкл, В. Е. Чудновский, И. Ялом и др.) психологов. Отмечено, что то, что В. Франкл назвал переживанием экзистенциального вакуума с соответствующими последствиями, И. Ялом - кризисом смысла, или кризисом бессмысленности, а С. Мадди - "малой смертью», или экзистенциальным неврозом, К. В. Карпинский называет смысложизненным кризисом, под которым понимает смысловой кризис в развитии личности, блокирующий, прежде всего, смысловую регуляцию и процессы смыслообразования индивидуального жизненного пути и определяющего его основные проявления, причиной чего являются проблемы с поиском или реализацией смысла жизни личности.

Выявлено, что смысложизненный кризис переживается человеком как длительный и / или острый внутренний конфликт между желаемым (жизненно необходимым, самым важным для него) и объективно возможным. При этом человек, даже представляя путь достижения желаемого, не всегда может им воспользоваться, что заставляет его принять все, как есть, и пытаться справиться с ситуацией. В переживании смысложизненного кризиса невозможно отделить внутренние и внешние его причины, поскольку он всегда переживается на субъективном уровне.

Сделан вывод, что жизнестойкость может быть использована для преодоления смысложизненного кризиса личности, минимизируя его негативные последствия и преврашая его в возможность развития личности через усвоение жизненных уроков и нахождение нового личностного жизненного смысла.

Ключевые слова: смысложизненный кризис, жизнестойкость, смысл жизни, вовлеченность, экзистенциальный невроз, кризис бессмысленности. 